\title{
Tenacity of mammalian viruses in the gut of leeches fed with porcine blood
}

\author{
Ahmad Al-Khleif, ${ }^{1}$ Manfred Roth, ${ }^{2}$ Christian Menge, ${ }^{3}$ Jörg Heuser, ${ }^{1}$ \\ Georg Baljer ${ }^{1}$ and Werner Herbst ${ }^{1}$ \\ ${ }^{1}$ Institute for Hygiene and Infectious Diseases of Animals, Justus Liebig University Gießen, \\ Frankfurter Str. 89, 35392 Gießen, Germany \\ ${ }^{2}$ Biebertaler Blutegelzucht GmbH, Talweg 31, 35444 Biebertal, Germany \\ ${ }^{3}$ Friedrich-Loeffler-Institut/Federal Research Institute for Animal Health, Institute of Molecular \\ Pathogenesis, Naumburger Str. 96a, 07743 Jena, Germany
}

Correspondence

Werner Herbst

werner.herbst@vetmed.uni-

giessen.de

Received 15 October 2010

Accepted 28 February 2011

\begin{abstract}
Leech therapy is currently considered to be of high therapeutic value in medicine. However, feeding leeches with fresh animal blood during the maintenance and reproduction phase bears the risk of transmission of zoonotic viruses to the patient. We hypothesize that this would be abolished by subjecting leeches to quarantine measures prior to use. The required duration of quarantine would depend on the maximum survival time of pathogens in contaminated leeches. In order to be able to estimate this survival time reliably, experiments were conducted with enveloped and non-enveloped mammalian viruses possessing either RNA or DNA. Leeches were fed porcine blood contaminated with bovine parvovirus (BPV), feline calicivirus (FCV), equine arteritis virus (EAV) and equine herpesvirus type 1 (EHV-1) and kept in aquaria at $10^{\circ} \mathrm{C}$. From week 6 after feeding onwards, some leeches were held at $30{ }^{\circ} \mathrm{C}$. Before feeding and at different time points thereafter, blood samples were taken from the leeches to determine residual virus infectivity. Prototype mammalian viruses were able to survive in inoculated leeches for considerable periods of time. When leeches were kept at $10^{\circ} \mathrm{C}$ throughout, reisolation of infectious virus from the leeches' abdominal cavity blood was no longer possible at 23 (FCV), 23 (EAV), 27 (EHV-1) and 29 (BPV) weeks after inoculation. Shifting the temperature to $30{ }^{\circ} \mathrm{C}$ in week 6 slightly reduced the duration of detection of infectious viruses to 15 (EAV and EHV-1), 21 (FCV) and 27 (BPV) weeks. These data indicate that the ability of mammalian viruses to survive in leeches theoretically poses a possible risk for patients unless adequate precautionary measures are adopted. Application of a quarantine period, e.g. 31 weeks (i.e. including an additional safety period) at $10{ }^{\circ} \mathrm{C}$, may be a suitable measure to significantly decrease this risk.
\end{abstract}

\section{INTRODUCTION}

Hirudo medicinalis, medicinal leeches, belong to the phylum Annelida. Leeches are temporary blood-sucking parasites and, during the time of sucking, secrete a wide variety of substances, some of which are of benefit for the host. An example is hirudin, which is best known for its anticoagulative effect. Hirudin is used in the treatment of inflammation of the middle ear (Seleznev et al., 1992), is used as a systemic anticoagulant and may prove useful for in vitro blood collecting systems. Medical use of leeches also includes treatment of black eyes (Seleznev et al., 1992).

Due to these beneficial secretions, leeches have been successfully applied to many ailments in humans for over 2000 years. The first documented attempts to use $H$. medicinalis for medicinal purposes date back to the time of

Abbreviation: $\mathrm{TCID}_{50}, 50 \%$ tissue culture infective dose.
Hippocrates. Leech therapy is also used in traditional Chinese medicine. Paintings of medicinal leeches have been found in pharaohs' tombs. The Solomon Parables also describe leech treatment in ancient medicine. The Roman physician Galen classified leech therapy as a method for achieving healthy balance. The use of leeches peaked between 1830 and 1850 in Europe, but subsequent shortages in delivery led to a decline in use. Currently, 100000 patients in Germany per year (about $0.1 \%$ of the total population) regularly use leeches for therapy, in particular to treat vascular diseases. Leech therapy has also become popular in veterinary medicine in recent years.

Most leeches feed as blood-sucking parasites on their preferred host (Mann, 1962). If the preferred host is not available, most leeches will feed on other classes of host. Some feed on the blood of humans and other mammals, whilst others parasitize fish, frogs, turtles or birds. 
Sanguivorous leeches can ingest an amount of blood several times their own weight at one meal. After feeding, the leech retires to a dark spot to digest its meal. Digestion is slow, which enables the leech to survive very long fasting periods of up to several months (Sawyer, 1981).

Although leeches may harbour zoonotic bacteria and/or viruses obtained by sucking from previous hosts, only a very limited number of cases of diseases transmitted by leeches have been reported. Examples of pathogens involved include Streptococcus sp., Clostridium tetani, classical swine fever virus and Aeromonas hydrophila (Adams, 1988; Dickinson \& Lent, 1984; Kaestner, 1982; Shope, 1957). However, a high incidence of infections, with Aeromonas spp. being one of the major pathogens, was reported after the application of medicinal leeches (Bauters et al., 2007). Leeches used for medicinal purposes in Germany are from natural habitats mainly in the Near East or are bred in German aquaculture plants. Before use, leeches from both sources are kept isolated for a distinct time period beginning from import or last blood meal in order to enable self-inactivation of possibly incorporated pathogens. An appropriate length of quarantine will depend on the maximum duration that pathogens remain viable inside the leeches, but such experiments have rarely been reported. Bacteriophages and bacteria, for example, persisted in large numbers for at least 6 months in the gut of experimentally infected leeches (Nehili et al., 1994). Hence, this study aimed to determine the survival time of prototypic mammalian viruses in leeches.

Groups of leeches were inoculated with two non-enveloped viruses, bovine parvovirus (BPV) and feline calicivirus (FCV), and two enveloped viruses, equine arteritis virus (EAV) and equine herpesvirus type 1 (EHV-1), by feeding them virus-contaminated porcine blood and they were maintained in aquaria. At the beginning of the experiment and at distinct times after inoculation, some leeches were euthanized and analysed for residual viral infectivity. We also tested whether different maintenance temperatures had an influence on virus survival time in leeches.

\section{METHODS}

Leeches. $H$. medicinalis leeches were obtained from Biebertaler Blutegelzucht $\mathrm{GmbH}$ and kept in the laboratory in aquaria at $10{ }^{\circ} \mathrm{C}$ until further use.

Viruses and cell cultures. The viruses used were two nonenveloped viruses (BPV, strain Haden; and FCV, strain CAL) and two enveloped viruses (EHV-1, strain RACH; and EAV, strain Bucyrus). Virus propagation was carried out in primary fetal calf lung cell cultures (BPV), feline embryo cells (FCV) or Vero cells (EHV-1 and EAV). Cells were grown in Eagle's minimal essential medium (MEM) supplemented with $5 \%$ fetal calf serum (FCS) and antibiotics. Logarithmic virus dilution series were prepared in MEM with $5 \%$ FCS, and $100 \mu$ of each dilution was inoculated in quadruplicate onto cell monolayers grown in 96-well microplates to determine virus titres. After incubation at $37{ }^{\circ} \mathrm{C}$ and $5 \% \mathrm{CO}_{2}, 50 \%$ tissue culture infective doses $\left(\mathrm{TCID}_{50}\right)$ were estimated according to the methods of Spearman (1908) and Kärber (1931).
Determination of virus survival in leeches. Leeches were inoculated by being fed virus-contaminated blood. Test virus suspensions were mixed 1:10 with warm porcine blood (obtained at a local abattoir; Schlachthof) and vortexed for 3 min to obtain a homogeneous virus suspension at a dose of at least $10^{5} \mathrm{TCID}_{50} \mathrm{ml}^{-1}$. In a preceding experiment, blood from the same source was tested by tissue culture inoculation and found to be free of cytopathic viruses. Contaminated blood was then fed to the leeches by filling condoms with $\sim 200 \mathrm{ml}$ contaminated blood and allowing the leeches to suck through the skin of the condoms. Leeches were placed in water-filled aquaria at a constant temperature of $10{ }^{\circ} \mathrm{C}$. After 6 weeks, the water temperature was increased to $30{ }^{\circ} \mathrm{C}$ in some aquaria.

Immediately after the leeches were fed and at 1-2-week intervals up to the end of the experiment, three leeches each were euthanized by freezing at $-70{ }^{\circ} \mathrm{C}$ for $1 \mathrm{~h}$. After thawing at $37^{\circ} \mathrm{C}$, the abdominal cavity was opened with scissors and the blood was collected in a syringe. To recover the viruses, the blood was frozen at $-20{ }^{\circ} \mathrm{C}$ for $20 \mathrm{~min}$, thawed at room temperature and then centrifuged at $2500 \mathrm{~g}$ for $5 \mathrm{~min}$. The supernatant was used to determine residual virus titres. Titres were expressed as mean titres from three leeches per time point. Additionally, at late time points, $1 \mathrm{ml}$ blood from each of the leeches was inoculated onto a cell monolayer grown in tissue culture flasks, with a resulting detection limit of $0.5 \log$ TCID $_{50} \mathrm{ml}^{-1}$.

Cryosafe tubes were filled with $1 \mathrm{ml}$ contaminated blood or virus suspension in PBS as controls. Control tubes were placed in the respective aquaria and tested for residual virus infectivity at the same time intervals as the leeches.

\section{RESULTS}

In the experiments at $10{ }^{\circ} \mathrm{C}$, survival times of EHV-1 and EAV in leeches were greater than in PBS. However, in each case, the maintenance of virus infectivity was lower in contaminated blood than in leeches (Fig. 1). Viruses were inactivated in the leeches to levels below the detection limit of the cell culture assay as late as 23 weeks (FCV), 23 weeks (EAV), 27 weeks (EHV-1) and 29 weeks (BPV) when the leeches were kept at $10{ }^{\circ} \mathrm{C}$ throughout. Increasing the maintenance temperature to $30{ }^{\circ} \mathrm{C}$ in week 6 resulted in only a slightly shorter survival time of the viruses: titres then dropped below the detection limit within 15 weeks (EAV, EHV-1), 21 weeks (FCV) and 27 weeks (BPV) (Fig. 2).

As shown in Fig. 1, infectious BPV could be detected in at least one of three leeches until week 27 after feeding. Virus suspended in PBS (control) was detected until week 37 (end of experiment) and remained at a titre as high as 5.0 $\log _{10} \mathrm{TCID}_{50} \mathrm{ml}^{-1}$. Blood controls contained infective virus until week 17. FCV survived in leeches until week 21, whilst virus was detected until week 23 in the PBS controls and until week 13 in the blood controls. Infectivity of EAV was observed in leeches until week 21. In blood and PBS controls, viable virus was present until weeks 11 and 15, respectively. EHV-1 virus titre persisted in leeches until week 25, but was only detected until weeks 19 and 21 in PBS and blood controls, respectively.

Leeches maintained at $30{ }^{\circ} \mathrm{C}$ from week 6 onwards after feeding harboured infectious BPV in at least one of three leeches up to 25 weeks after inoculation (Fig. 2). Virus 


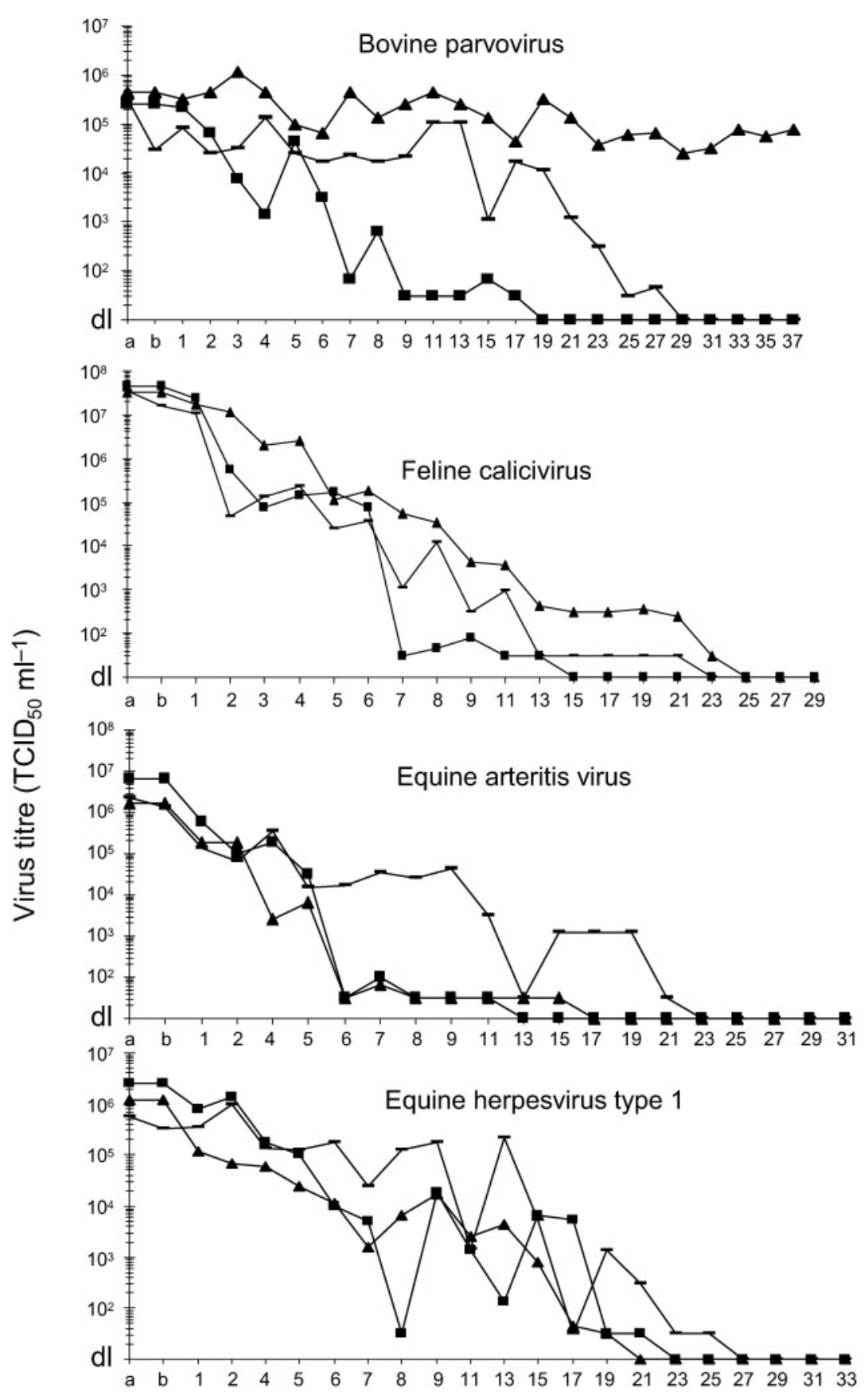

Time (weeks)
Fig. 1. Virus titres in the abdominal cavity of leeches fed with virus-contaminated porcine blood and maintained in aquaria at a temperature of $10{ }^{\circ} \mathrm{C}$ throughout. $\boldsymbol{\Delta}$, Virus control in PBS; $\mathbf{\square}$, virus control in blood; -, blood samples from leeches (arithmetic means of three calculations). a, Contaminated blood before feeding; $b$, blood directly after feeding; $\mathrm{dl}$, detection limit $\left(0.5 \log \mathrm{TCID}_{50} \mathrm{ml}^{-1}\right)$. controls with porcine blood remained infective until week 13. However, BPV in the PBS control remained infectious to the end of the experiment (week 31). FCV was isolated from leeches until week 19. FCV virus suspensions in PBS and porcine blood remained infectious until weeks 15 and 11, respectively. EAV was shown to remain infectious in leeches until week 13 after feeding, with the blood and PBS controls both remaining positive until week 8. EHV-1 infectivity was detected until week 13 in the blood recovered from the leeches, as well as in both controls.

\section{DISCUSSION}

The application of leeches in human medicine is currently considered to be of high value, in particular for the treatment of vascular diseases. However, medical application may pose a risk of patients becoming infected with different zoonotic agents. The reason for this hypothesis is that leeches maintained in leech plants have to have blood meals before being distributed to medical practitioners. Both imported leeches from the Near East, which have 

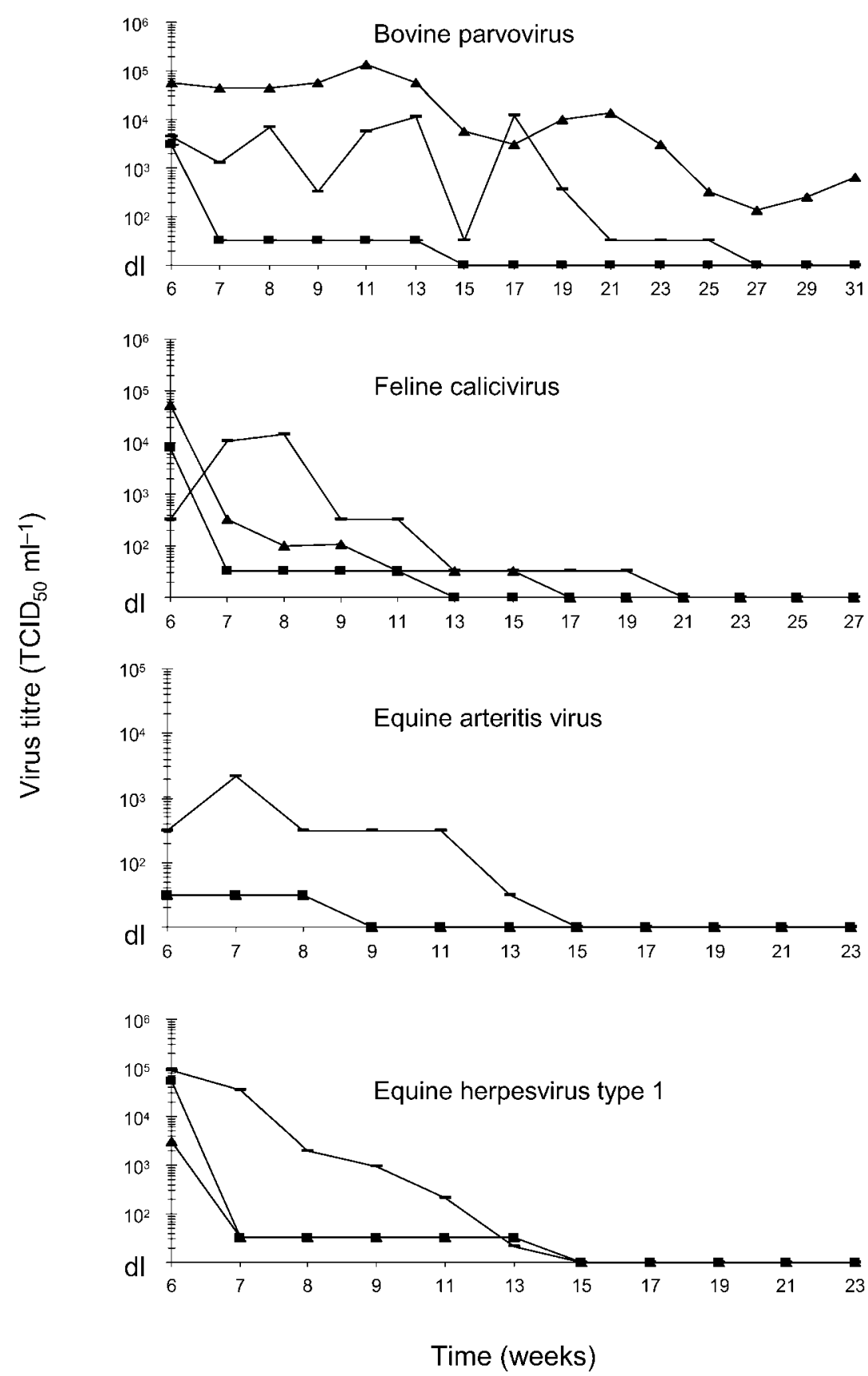

Fig. 2. Virus titres in the abdominal cavity of leeches fed with virus-contaminated porcine blood and maintained in aquaria at temperatures of $10^{\circ} \mathrm{C}$ for the first 6 weeks after feeding and at $30{ }^{\circ} \mathrm{C}$ thereafter. $\boldsymbol{\Delta}$, Virus control in PBS; $\mathbf{\square}$, virus control in blood; -, blood samples from leeches (arithmetic means of three calculations). dl, Detection limit (0.5 $\log \mathrm{TCID}_{50} \mathrm{ml}^{-1}$ ). sucked blood from wild animals, as well as domestic-bred leeches, which are mostly fed with porcine blood, have an inherent risk of carrying pathogens, such as hepatitis E virus, from swine blood. This risk may be decreased by isolation of the leeches for a distinct quarantine time. The required duration of quarantine is presently unknown but depends strongly on the potential survival time of mammalian viruses in the gut of leeches. Therefore, a study was undertaken to determine how long mammalian viruses can remain infectious after inoculation of leeches.

The survival of viruses depends mainly on the tenacity of the viruses used and the ambient temperature but also on different unknown environmental conditions. Accordingly, test viruses were chosen for this study based primarily on their tenacity but also for their ability to replicate in permanent cell lines, to propagate to high titres and to induce pronounced cytopathic effects. BPV, FCV, EAV and EHV-1 were selected. EAV and EHV-1 are known to be of low tenacity (Liess \& Kaaden, 2003; Mahnel, 1983; Rolle \& Mayer, 2002; Schliesser \& Strauch, 1981), but their stability towards harmful environmental factors is higher than that of, for example, human immunodeficiency virus. FCV was included in this study because of its high tenacity, which is comparable to that of adenoviruses and reoviruses, which are widespread in animals. BPV is one of the most stable 
mammalian viruses. It withstands treatment with a variety of chemical substances and has a thermal stability comparable to that of papillomaviruses (Brown, 1981). BPV remains infective for more than a year at $4{ }^{\circ} \mathrm{C}$, for 13 months at room temperature, for 5 months at $37^{\circ} \mathrm{C}$, for $1-$ 2 days at $56{ }^{\circ} \mathrm{C}$ and for $1-3 \mathrm{~h}$ at $80{ }^{\circ} \mathrm{C}$ (Siegel, 1976; Wigand et al., 1981). In fact, BPV could be reisolated from the leeches for the longest time when compared with the other test viruses. Few studies on the tenacity of viruses in leeches have been published previously. Reported survival times of 12-20 weeks for classical swine fever and myxoma viruses (Shope, 1957) are in good agreement with the results of this study.

Surprisingly, the enveloped viruses EHV-1 and EAV, known to be very sensitive to environmental conditions, both showed a rather long survival time. In the case of EHV-1, this time was shorter (25 weeks) than that for BPV (27 weeks) but longer than that of FCV and EAV (21 weeks). A human virus that has similar environmental resistance to EHV-1 and FCV is hepatitis B virus (HBV). From the data of this study, it could be concluded that HBV might also maintain infectivity for some 21-25 weeks. The results from assessment of the virus control in porcine blood indicated that, in almost all experiments, survival times were longer in leeches than in the blood samples. This suggests that substances exist in the leeches that might conserve virus infectivity. These substances may relate to or even be identical to those that are secreted into the intestines of the leeches after a blood meal in order to keep the blood fresh for a long time. Of note, the tenacity of viruses in leeches may thus differ from their tenacity towards disinfectants. Concentrations used to disinfect non-enveloped viruses usually exceed the concentrations needed to inactivate enveloped viruses. The results of this study showed that this general assumption cannot be extended to the conditions present in leeches. It is essential for further studies to include not only stable nonenveloped viruses but also enveloped viruses that are otherwise considered to be less stable. In contrast, the genome of the viruses (DNA or RNA) appeared not to influence the maintenance of virus infectivity in leeches.

Consequently, it is also essential to differentiate between enveloped and non-enveloped rather than between RNA and DNA viruses if rules for the quarantine times of leeches after feeding in advance of medical application are to be put in place. If this is not applicable, recommendations for quarantine times should be based on studies with extremely stable viruses. BPV belongs to this group of viruses. In fact, this study revealed the longest survival time for this agent in leeches. FCV, which represents a stable virus when considering its tenacity towards disinfectants (Al-Khleif et al., 2009), turned out to be less suitable as a test virus given that EHV-1 survived in leeches for longer. We suggest that studies with BPV are the most meaningful to determine the appropriate time that leeches need to be kept in quarantine to prevent possible transmission of viruses. In our studies, the survival time of BPV in leeches kept at $10{ }^{\circ} \mathrm{C}$ was 27 weeks and slightly less if the leeches were kept at $30{ }^{\circ} \mathrm{C}$ starting from week 6 . Time savings by application of higher temperatures will therefore be unexpectedly low. It is probable that the extraordinarily high heat stability of BPV, a characteristic of this virus (Herbst et al., 1990), is responsible for this phenomenon. In conclusion, our studies indicated that, if another 4 weeks are added, a quarantine period of a total of 31 weeks at $10{ }^{\circ} \mathrm{C}$ between the last blood feed and the distribution of the leeches to medical practitioners should sufficiently diminish the risk of transmitting viral infections by leech therapy.

\section{REFERENCES}

Adams, S. L. (1988). The medicinal leech. A page from the annelids of internal medicine. Ann Intern Med 109, 399-405.

Al-Khleif, A., Baljer, G. \& Herbst, W. (2009). Prüfung von Bioziden auf Wirksamkeit gegen animale Viren nach EU-Normen im Hinblick auf die Auswahl eines geeigneten Testvirus. Berl Münch Tierärztl Wochenschr 122, 58-62.

Bauters, T. G. M., Buyle, F. M. A., Verschraegen, G., Vermis, K., Vogelaers, D., Claeys, G. \& Robays, H. (2007). Infection risk related to the use of medicinal leeches. Pharm World Sci 29, 122-125.

Brown, T. T., Jr (1981). Laboratory evaluation of selected disinfectants as virucidal agents against porcine parvovirus, pseudorabies virus, and transmissible gastroenteritis virus. Am J Vet Res 42, 10331036.

Dickinson, M. H. \& Lent, C. M. (1984). Feeding behavior of the medical leech, Hirudo medicinalis, L. J Comp Physiol A 154, 449455.

Herbst, W., Wekerle, J. \& Strauch, D. (1990). Zur inaktivierenden Wirkung organischer Säuren auf Parvoviren bei verschiedenen Temperaturen. Hyg Med 122, 313-317.

Kaestner, A. (1982). Lehrbuch der speziellen Zoologie. In Wirbellose Tiere. Teil 3. Vierte bearbeitete Auflage, vol. 1, pp. 621. Edited by H. E. Gruner. Stuttgart: Gustav Fischer.

Kärber, G. (1931). Beitrag zur kollektiven Behandlung pharmakologischer Reihenversuche. Arch Exp Pathol Pharmakol 162, 480483.

Liess, B. \& Kaaden, O. R. (2003). Virusinfektionen bei Haus- und Nutztieren. Haussäugetiere - Fische - für Studium und Praxis, 2. Auflage, Hannover: Schlütersche Verlag.

Mahnel, H. (1983). Desinfektion von Viren. Zentralbl Veterinarmed B 30, 81-96.

Mann, K. H. (1962). Leeches (Hirudinea): Their Structure, Physiology, Ecology and Embryology. Oxford: Pergamon Press.

Nehili, M., Ilk, C., Mehlhorn, H., Ruhnau, K., Dick, W. \& Njayou, M. (1994). Experiments on the possible role of leeches as vectors of animal and human pathogens: a light and electron microscopy study. Parasitol Res 80, 277-290.

Rolle, M. \& Mayer, A. (2002). Medizinische Mikrobiologie, Infektionsund Seuchenlehre, 7. Auflage. Stuttgart: Enke Verlag.

Sawyer, R. T. (1981). Leech biology and behaviour. In Neurobiology of the Leech, pp. 7-26. Edited by K. J. Muller, J. G. Nicholls \& G. S. Stend. Cold Spring Harbor, NY: Cold Spring Harbor Laboratory.

Schliesser, T. \& Strauch, D. (1981). Desinfektion in Tierhaltung, Fleisch- und Milchwirtschaft. Stuttgart: Enke Verlag. 
Seleznev, K. G., Shchetinina, E. A., Trophimenko, N. P., Nikonov, G. I. \& Baskova, I. P. (1992). Use of the medicinal leech in the treatment of ear diseases. ORL J Otorhinolaryngol Relat Spec 54, 1-4.

Shope, R. E. (1957). The leech as a potential virus reservoir. J Exp Med 105, 373-382.

Siegel, G. (1976). The parvoviruses. Virol Monogr 15, 4.
Spearman, C. (1908). The method of "right and wrong cases" ("constant stimuli") without Gauss's formulae. Br J Psychol 2, 227242.

Wigand, R., Bachmann, P. A. \& Brandner, G. (1981). Stabilization of isometric DNA viruses against thermoinactivation by lowered ionic strength. Arch Virol 69, 61-69. 